\begin{tabular}{ll}
\hline 臨 & 床 \\
\hline
\end{tabular}

他覚的耳鳴の 2 症例

小出 千秋・今井 昭雄・長場 章*

\title{
Objective Tinnitus; A Report of Two Cases
}

\author{
Chiaki Koide and Akio Imai \\ (Niigata Civil Hospital) \\ Akira Nagaba \\ (Niigata University)
}

A 9-year-old boy had click-like objective tinnitus generated by a voluntary palatal movement. No treatment was performed because the tinnitus was completely controllable. A 62-year-old woman complained of click-like objective tinnitus associated with expiration. The electromyogram revealed activity of the tensor veli palatini muscle associated with the tinnitus. Carbamazepine did not cure the tinnitus. Pterygoid hamulotomy stopped the tinnitus temporarily but it reappeared two weeks later.

Key words: objective tinnitus, muscular tinnitus, pterygoid hamulotomy

\section{緒言}

他覚的耳鳴は比較的まれな疾患であるが，本 邦ではすでに170例を越える報告がなされてい る1)。 その原因として筋性耳鳴が最も多く，血 管性耳鳴がそれに次いでいる．今回われわれは 随意性筋性耳鳴の一例と不随意性筋性耳鳴の一 例を経験したので報告する。

\section{症例}

症例 1 .

9 歳, 男児.

主訴 : 右耳鳴.

初診：1990年 4 月 21 日.

家族歷・既往歴：特記すべきことなし.

現病歴：1989年10月頃からカチカチといら右
耳鳴を自覚していた．家族もこの耳鳴を聴取で きたため当科を受診した. また本人は耳鳴を随 意的に起したり止めたりすることができると述 ベた。

現症: 全身, 耳鼻咽喉とも器質的異常はみら れなかった。 また聴力は正常で耳 X線でも異常 はみられなかった。耳鳴は防音室で約 $1 \mathrm{~m}$ 離 れて聴取可能であった。随意的に耳鳴を出させ るとき，患児は軟口蓋の痤攣様運動を起してい た。 また耳鳴は挙上した軟口蓋が降りる際に起 ることがわかった. 耳鳴出現時の鼓膜の運動を 顕微鏡下で観察したが, 鼓膜の運動は認められ ずまたティンパノグラムの記録でも耳鳴に一 
致した波動はみられなかった。耳鳴は $\mathrm{KAY}$ 社 製 DSP ソナグラムNo.5500にて分析した（図 1 ). 耳鳴の周波数は $3400 \mathrm{~Hz}$ にピークがあり， $2000 \mathrm{~Hz}$ から $4800 \mathrm{~Hz}$ に及んでいた．持続時間 は約 $2 \mathrm{msec}$ であった。

経過：耳鳴は全く随意的にコントロールする ことができることと，本人の苦痛がなかったの で無処置とした.

症例 2 . 62歳, 女性.

主訴 : 左耳鳴.

初診：1990年 5 月 8 日.

家族歴・既往歴 : 特記すべきことなし。

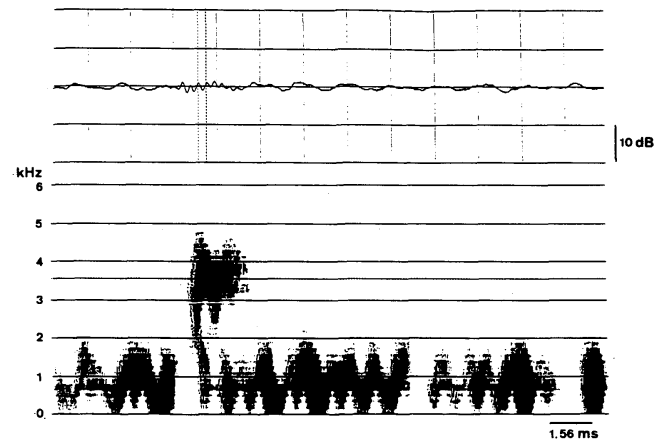

図 1 症例 1 のソナグラフ 上段は再生レベルのパターン分析で縌軸は音圧, 横軸は時間を示す。下段はこれを $8 \mathrm{kHz}$ までの 間で拡大したもの. $2 \mathrm{kHz}$ までの雑音に重なって $2000 \mathrm{~Hz}$ から $4800 \mathrm{~Hz}$ に及ぶ持続時間約 $2 \mathrm{msec}$ の耳鳴がみられる。

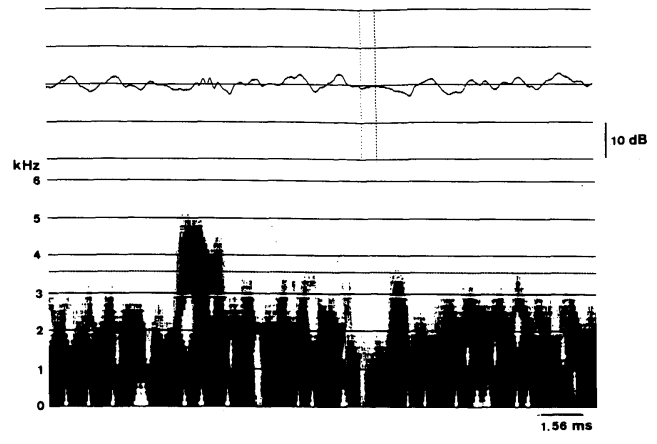

図 2 症例 2 のソナグラフ

$3 \mathrm{kHz}$ までの雑音に重なって $2000 \mathrm{~Hz}$ から 5000 $\mathrm{Hz}$ に及ぶ持続時間約 $2 \mathrm{msec}$ の耳鳴がみられる.
現病歴：1988年 5 月頃から左耳閉感が出現し, 同年12月からカッカッといら耳鴂に変化した. 某耳鼻科を受診し治療を受けたが改善しないた め当科を受診した．耳鳴は呼気の際に出現する が吸気の際には起こらず，感冒で鼻閉のあると きや息こらえをしたときにも起こらないと述べ た。

現症 : 左鼓膜は辺縁が肥厚し, 中央が菲薄化 していた. 聴力は右正常, 左は平均 $25 \mathrm{~dB}$ の 高音漸傾型感音難聴であった。鼻咽腔には器質 的異常はみられなかった。耳 X線で異常はみら れなかった．耳鳴は防音室で $40 〜 50 \mathrm{~cm}$ 離れ

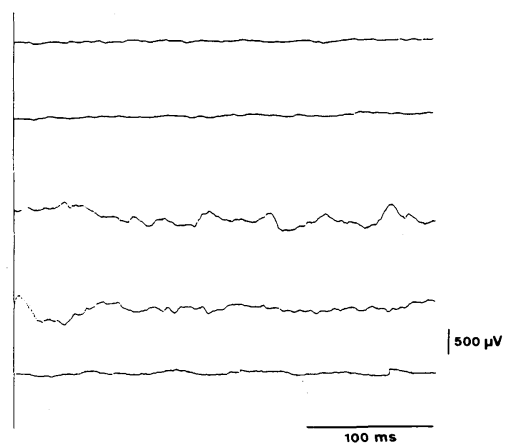

図 3 症例 2 の耳管開口部付近より記録 した筋電図

上段から下段に向かって経時的に記録されて いる. 持続時間約 $650 \mathrm{msec}$ の活動電位がみ られる。

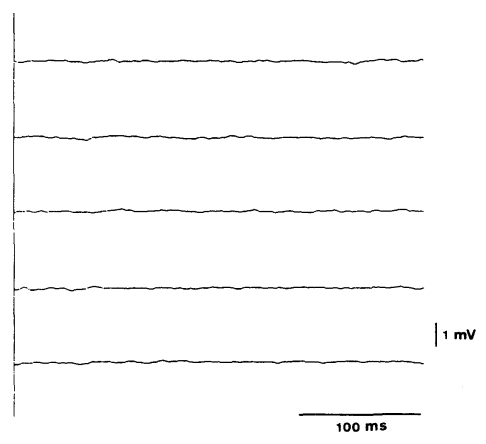

図 4 症例 2 の軟口蓋より記録した筋電図 筋肉の活動電位は記録されていない。 
て聴取可能であった．耳鳴発現時に顕微鏡で鼓 膜を観察したが，明らかな鼓膜の運動はみられ なかった．左耳管開口部をファイバースコープ で観察したところ, 呼気の際に耳管後唇と軟口 蓋上縁の運動が認められた。息こらえをすると 耳鳴は消失し，また生食ガーゼを上咽頭，耳管 開口部に当てると耳鳴は消失した，耳鳴の周波 数は $3700 \mathrm{~Hz}$ にピークがあり，2000 Hz から $5000 \mathrm{~Hz}$ に及んでいた。持続時間は約 $2 \mathrm{msec}$ であった(図 2 )。耳管開口部付近の軟口蓋上縁 から記録した筋電図を図 3 亿示した。 またこの 運動は右耳管後唇と軟口蓋上縁でも起っていた. 開口による耳鳴の減弱はみられず，また口腔側 からの軟口蓋の運動は肉眼的にも筋電図(図 4) でもみられなかった。

経過：最初に Carbamazepine (商品名：テグ レトール®) $200 \mathrm{mg}$ の内服を 7 日間行ったが，

眠気を催すのみで耳鳴の改善はみられなかった。 次に耳鳴と同期して耳管後唇下部が咽頭後壁と 接触する運動がみられたので，田林ら2)の例の ようにこの接触が耳鳴を起こす可能性を考え ローゼンミューラー窩を狭くする目的で上咽頭 後壁に生食 $2 \mathrm{ml}$ を注入したところ耳鳴は一旦 消失したが，数分後元へ戻った。そこで声帯注 入用シリコン $0.4 \mathrm{ml}$ を上咽頭後壁の耳管後唇 近傍に注入しローゼンミューラー窩を狭くした が耳鳴は消失せず，これ以上のンリコン注入を 中止した. 次に1990年 9 月 3 日翼突鈎切除術と 口蓋帆張筋切断術を全身麻酔下に行った. 手術 直後より 2 週間は耳鳴は完全に消失したが，そ の後耳鳴は再発した. しかし患者は耳鳴が以前 ほど気にならなくなったと述べた。

\section{考察}

1. 他覚的耳鳴の分類と機序

Atkinson ${ }^{3)}$ は他覚的耳鳴をその原因から，1） 血管性，2)筋肉性，3)鼻咽腔の異常によるも の(呼吸性)，4）頕関節の異常によるものに分 類した。島村ら ${ }^{1)}$ は他覚的耳鳴を，1）筋性, 2 ) 血管性，3) その他(異物, 頸椎由来など)に 分類した。な陉佐藤ら ${ }^{4)}$ は新しいカテゴリーと
してキーンといら高調の持続音である強大な自 発耳音響放射による他覚的耳鳴例を報告してい る. 筋性耳鳴の音源について熊澤ら5) は耳管由 来として耳管管腔離着音と耳管管腔空気通過音, 軟口蓋由来として軟口蓋と咽頭後壁の離着音と 軟口蓋筋自体の収縮音, 鼓室由来として耳小骨 筋の収縮音が考兄られると述べている．筋性耳 鳴の多くは軟口蓋のミオクローヌスに伴って起 るが，ミオクローヌスのみられない症例も多い。 ミオクローヌスの原因として山本ら ${ }^{6)}$ (破瓜病 が主因で, 鼻咽腔線維腫が誘因となったと推定 される軟口蓋間代性痤攣による耳鳴の一例を報 告したが，さらに心因，精神神経症的因子，自 律神経機能障害も原因として挙げている，中江 $5^{7)}$, 成瀬8) も精神神経症的因子を原因に数古 ている. ミオクローヌスが器質的疾患が原因で ある場合, 渋沢ら ${ }^{9)}$ は脳血管障害によるものが 最多であると述べ，猪ら ${ }^{10)}$ は cerebello-vestibular connection の病変により起ることが多い と述べている.

Quarry ${ }^{11)}$ は角膜に空気を吹き付けたところ 耳鳴が消失した症例を示し，三叉神経による反 射経路により口蓋帆張筋を抑制する経路を考え た。また Quarry の症例は呼吸を止めることに より耳鳴が消失したが，脳幹網様体下部の呼吸 中枢と三叉神経運動核が連絡をもち，第 5 脳神 経下顎枝を介してロ蓋帆張筋を抑制したのでは ないかと推定した．われわれの症例 2 の耳鳴も 呼気に同期して出現し, 呼吸を止めると耳鳴も 停止したので，呼吸中枢と三叉神経運動核の間 に何らかの連絡が生じていたのではないかと考 えられた。また神経の異常放電が三叉神経運動 路核に限局せず, 他の頭頸部諸筋の運動神経核 にも及ぶ場合があり, 軟口蓋ミオクローヌスに よる他覚的耳鳴例では軟口蓋以外の随伴運動を 伴うことがある. 頸部の運動を伴うもの ${ }^{12)}$, 舌 ・喉頭に及ぶもの ${ }^{13)}$, 顔面チック，胸鎖乳突筋， 側頭筋, 頓筋の収縮を伴うもの14)などが報告 されている. 


\section{2. 他覚的耳鳴の性質と診断}

血管性耳鳴は脈拍と同期し，低調性の音であ る. 中江ら ${ }^{7)}$ の例では1.5から $2.5 \mathrm{kHz}$ 飞分布 していた．耳小骨筋性耳鳴のうちアブミ骨筋性 耳鳴は 4 秒程度と持続時間が長く15), 音色は低 調性で周波数は約 $125 \mathrm{~Hz}$ または約 $250 \mathrm{~Hz}$ で あったといら報告 ${ }^{16)}$ がある。耳管の空気通過 音は持続時間 $300 \mathrm{msec}$ と耳管の離着音に比較 して長( 脈拍之同期しない高調性の持続時間の短いクリ ック音である. 周波数 $2000 \sim 4800 \mathrm{~Hz}$ で持続 時間 $120 \mathrm{msec}^{17)}, 1800 \mathrm{~Hz}$ にピークがあり 10000 $\mathrm{Hz}$ までの周波数にわたる症例と $2000 \mathrm{~Hz}$ に ピークがあり $7000 \mathrm{~Hz}$ までの周波数にわたり持 続時間 $8 \mathrm{msec}$ の症例1)，周波数は $500 \sim 8000$ $\mathrm{Hz}$ にわたり，2000，4000 Hz ヒピークがある症 例12)などが報告されている。われわれの症例 では周波数のピークは 1 例目が $3400 \mathrm{~Hz} ， 2$ 例

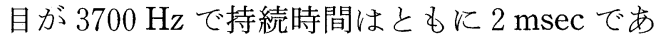
った。また耳管カテーテルを耳管内へ挿入する と耳鳴が減弱ないし消失するといら報告7)17)18) がある.耳管管腔離着音は耳管が開く時と閉じ る時のどの音であるかについては，Pulec ら ${ }^{19}$ は軟口蓋が降りてくる時に耳鳴がするので，耳 管が閉じる際に発生する音であると考えたが， 熊澤らは耳管管腔の急激な離解が耳鳴の原因で, 接着ではクリック音が出ない5) と述べている.

耳管の運動に関与する筋には口蓋帆挙筋と口 蓋帆張筋とがあるが，口蓋帆挙筋は軟口蓋の挙 上と耳管隆起の内後上方への移動に作用し, 口 蓋帆張筋は耳管の開大に作用寸る ${ }^{20)}$. 軟口蓋の 㾏攣を認めた症例で筋電図にて口蓋帆張筋と口 蓋帆挙筋の両方の放電を記録したといら報告 ${ }^{13)}$ があり，軟口蓋の痤攣を認めなかった症例で口 蓋帆挙筋の放電以記録されず，口蓋帆張筋のみ の放電を記録したといら報告17) とがある。し かし軟口蓋の瘥攣を認めなかった症例でも口蓋 帆張筋と口蓋帆挙筋の両方の放電を記録したと い5報告21) もある. Rahko ら ${ }^{22)}$ は軟口蓋痤攣 は肉眼上すべて観察しらるものではないとして,
筋電図の使用をす寸女ている．われわれの症例 2 は口腔からは軟口蓋の運動がみられず，口腔 側からの筋電図でも口蓋帆挙筋の放電を記録で きなかったが，ファイバースコープを用いるこ とにより軟口蓋のわずかな動きを確認すること ができた。 また口蓋帆張筋が耳鳴の原因である ことを確認する方法として, 三叉神経第 3 枝の ブロックにより耳鳴が消失すれば，三叉神経第 3 枝支配の口蓋帆張筋が原因であるとする柴18) の方法がある。

\section{3。治療}

ミオクローヌスによる耳鳴に対する薬物治療 とその効果を文献より調べると，a）メジャ一 トランキライザー (Haloperidol) は有効17)， b ) マイナートランキライザー(Diazepam など)が 有効5)23)，無効177)17)24)， c ) 抗痤攣剂(Carbamazepine など)が有効22)，無効1117)24)，骨格筋弛緩 剂が無効1724)，d）自律神経安定剂は無効24), e ) 星状神経節ブロックは無効17) という結果で あった。薬剤による治療は有効とする報告と無 効とする報告とがあり，一定した結論が得られ ていない。われわれの症例 2 では Carbamazepine が無効であった。

耳管性耳鳴に対し耳管ブジー挿入を反復して 耳鳴を停止させた24)という報告や，咽頭後壁 にシリコンを注入してローゼンミューラー窩を 狭くしたところ耳鳴が消失したといら報告2)が ある.われわれの症例 2 では咽頭後壁への生食 やシリコンの注射を試みたが耳鳴の消失は確実 ではなかった。

軟口蓋ミオクローヌスによる他覚的耳鳴の外 科的治療法として, 翼突鈎切断術 pterygoid hamulotomy がある。この方法により榊原ら 25) の例では耳鳴が軽減し, 山本ら ${ }^{21)}$ の例では耳 鳴の強さと回数は減少したが完全には消失せ ず，柴18) の例では術後耳鳴は一旦消失したが 9 日後より再発している.われわれの症例 2 で も術後耳鳴が完全に消失したが，2 週間後から 耳鳴が再発した。翼突鈎切断術は耳鳴の軽減に 効果があるものの，耳鳴を全く消失させるには 
至らないように思われた。

軟口蓋ミオクローヌスの機序の一つには心因 の関与があり, 精神療法が必要とされる26) と いら. 暗示による精神療法で耳鳴が消失したと いら例14)や，鼻手術・抗攣縮剤ムスカルム® の内服・説明による精神の安定を組み合わせて 耳鳴が軽快した例13) もある。一方他覚的耳鳴 は日常生活に支障を来さない限りは積極的に治 療を行ら必要はなく, 経過観察で十分であると 言われている119)。不随意的他覚的耳鳴でも 6 歳の小児で自然消失例の報告27)や，長期間の 経過観察の結果数週間から10年の間に耳鳴が自 然消失する例が多い28) といら報告もある.

\section{結 語}

他覚的筋性耳鳴の 2 例を経験した，症例 1 は 9 歳の男児で, 軟口蓋の随意的な挙上運動によ り起る周波数 $3400 \mathrm{~Hz}$ のクリック様耳鳴であ った．耳鳴は完全に随意的にコントロールでき たので無処置とした. 症例 2 は62歳の女性で, 呼吸運動之関連のある周波数 $3700 \mathrm{~Hz}$ のクリ ック様耳鳴であった。耳鳴側の pterygoid hamulotomy によって耳鳴は一時完全に消失し たが， 2 週間ののち再発した。

耳鳴の周波数分析には永島医科器械株式会社の協 力を得た。

本論文の要旨は第31回日耳鼻新潟県地方部会にて 口演した.

\section{文献}

1）島村康一郎, 渡辺徳武, 植山茂宏, 他: 他覚的 随意的耳鳴の 2 症例. 耳鼻臨床 $81 ： 1739 \sim 1744$, 1988 .

2) 田林徳昭, 佐藤宏昭, 本庄 餀 : Rosenmüller 窩由来の他覚的耳鳴. 耳鼻臨床 $81: 1745 \sim 1748$, 1988.

3) Atkinson $\mathrm{M}:$ Tinnitus aurium. Arch Otolaryngol $45: 68 \sim 76,1947$.

4）佐藤信清, 吉鶴博生, 酒井 昇, 他: 他覚的耳 鳴(自発耳音響放射) 呈した家族症例。臨床耳 科 $14: 208,1987$.

5）熊澤忠躬, 本庄 撖, 本田啓二, 他 : 他覚的随
意的耳鳴の検討 一耳鳴発生部位とその機構の 考察一. 耳鼻臨床 $66: 387 \sim 392,1973$.

6）山本常市, 市原正雄, 小松 晃: 他覚的耳鳴に 就いて. 耳喉 $30: 708 \sim 716,1958$.

7) 中江 進, 大梘晃直, 村上 匡, 他: 他覚的耳 鳴 5 例 一血管性耳鳴 1 例之耳管筋性耳鳴 4 例一。 松化会医誌 $27 ： 159 \sim 168,1988$.

8）成瀬紀雄：軟口蓋間代性㾏攣に因る他覚的耳鳴 の一例. 耳鼻臨床 $36: 239 \sim 253,1941$.

9）啮沢三伸, 大久保化, 渡辺 勈, 他: 口蓋ミ才 クローヌス一他覚的耳鳴について一. 臨床耳科 $13: 66 \sim 67,1986$.

10）猪 忠彦, 古賀慶次郎, 神崎 壬, 他: 他覚的 耳鳴の三症例. Audiology Japan 16:77 80, 1973.

11) Quarry JG : Unilateral objective tinnitus; a case and a cure. Arch Otolaryngol $96: 252 \sim$ 253, 1972.

12）竹越省一：随意性他覚的耳鳴の 2 症例. 耳喉 $40: 25 \sim 30,1968$.

13）白幡雄一，笠原行善：軟口蓋間代性痤攣を伴亏 所謂他覚的耳鳴の 1 例. 耳展 $17: 231 \sim 239$, 1974.

14) Schwartz HW : Head noises of muscular origin; audible or objective tinnitus. J Laryngol Otol $62: 746 \sim 751,1948$.

15）永浜武彦：筋肉性耳鳴. 耳喉 $56: 645 \sim 648$, 1984.

16）渡辺 勈, 隈上秀伯, 津田祥明 : アブミ骨筋異 常收縮に伴う耳鳴について. Audiology Japan $16: 81 \sim 88,1973$.

17）野添恒幹, 和田安弘, 木下卓也, 他: 鼓膜張筋 痤攣を伴ったいわゆる耳管性耳鳴の一症例.耳 鼻臨床 $78: 1041 \sim 1049,1985$.

18）柴 良武：口蓋帆張筋痤攣による他覚的耳鳴症 例. 耳鼻臨床 $73: 1573 \sim 1579,1980$.

19) Pulec JL and Simonton KM : Palatal myoclonus; a report of two cases. Laryngoscope $71: 8 \sim 671,1961$.

20) Dickson DR : Anatomy of the normal velopharyngeal mechanism. Clin Plast Surg $2: 235 \sim 248,1975$.

21）山本悦生, 福島英行, 森中節子, 他: 耳管筋性 他覚的耳鳴の一例. Audiology Japan 21:415 
$\sim 416,1978$.

22) Rahko $T$ and Häkkinen $V$ : Carbamazepine in the treatment of objective myoclonus tinnitus. J Laryngol Otol 93 : 123 127, 1979.

23）稲村博雄, 青柳 優, 戸島 均, 他 : 他覚的耳 鳴の 2 症例. 臨床耳科 $14: 132,1987$.

24）村上忠也, 服部康夫, 弓削庫太：コントロール しえた他覚的耳鳴の 1 例. 臨床耳科 $14: 131$, 1987.

25）榊原淳二, 加納直行, 野村 淳: 他覚的耳鳴の 2 症例. 目耳鼻 $91: 120,1988$.

26) Leventon G, Man A and Floru S : Isolated psychogenic palatal myoclonus as a cause of objective tinnitus. Acta Otolaryngol $65: 391$ $\sim 396,1968$.

27) Litman RS and Hausman SA : Bilateral palatal myoclonus. Laryngoscope $92: 1187 \sim 1189$, 1982 .

28) Hentzer E : Objective tinnitus of the vascular type; a follow up study. Acta Otolaryngol $66: 273 \sim 281,1968$.

$\left(\begin{array}{l}\text { 原稿受付: 平成 } 3 \text { 年 } 1 \text { 月 } 28 \text { 日 } \\ \text { 原稿採択 : 平成 } 3 \text { 年 } 3 \text { 月 } 19 \text { 日 } \\ \text { 別刷請求先 : 小出千秋 } \\ \text { 厂 } 950 \text { 新潟市紫竹山 } 2 \text { 丁目 } 6-1 \\ \text { 新潟市民病院耳鼻咽喉科 }\end{array}\right)$

